\title{
Vitrification of in Vivo-derived Porcine Morulae and Blastocysts Alters Metabolic and Stress Response Pathway Alterations
}

\section{Cristina Cuello}

Department of Medicine and Animal Surgery, Faculty of Veterinary Medicine, International Excellence Campus for Higher Education and Research "Campus Mare Nostrum", University of Murcia

Cristina A. Martinez ( $\nabla$ cristina.martinez-serrano@liu.se )

Linkopings universitet https://orcid.org/0000-0001-6811-0191

\section{Josep M Cambra}

Department of Medicine and Animal Surgery, Faculty of Veterinary Medicine, International Excellence Campus for Higher Education and Research "Campus Mare Nostrum", University of Murcia Inmaculada Parrilla

Department of Medicine and Animal Surgery, Faculty of Veterinary Medicine, International Excellence Campus for Higher Education and Research "Campus Mare Nostrum", University of Murcia

\section{Heriberto Rodriguez-Martinez}

Department of Biomedical \& Clinical Sciences (BKV), BKH/Obstetrics \& Gynaecology, Faculty of Medicine and Health Sciences, Linköping University

\section{Maria A Gil}

Department of Medicine and Animal Surgery, Faculty of Veterinary Medicine, International Excellence Campus for Higher Education and Research "Campus Mare Nostrum", University of Murcia

\section{Emilio A martinez}

Department of Medicine and Animal Surgery, Faculty of Veterinary Medicine, International Excellence Campus for Higher Education and Research "Campus Mare Nostrum", University of Murcia

\section{Research}

Keywords: embryo, vitrification, transcriptome, morula, blastocyst, pig

Posted Date: June 17th, 2020

DOI: https://doi.org/10.21203/rs.3.rs-35496/v1

License: (9) This work is licensed under a Creative Commons Attribution 4.0 International License. Read Full License 


\section{Abstract}

\section{Background}

Despite reported promising farrowing rates after non-surgical and surgical transfers of vitrified in vivoderived porcine morulae and blastocysts (range: $70-75 \%)$, their pregnancy loss is yet higher (10-20\%) than it is for fresh embryos ( $<2.5 \%)$. The present study was designed to investigate whether vitrification would affect the transcriptome of porcine morulae and blastocysts, using microarrays and qRT-PCR validation.

\section{Material and methods and results}

Morulae and blastocysts were collected from weaned sows $(n=13)$ by laparotomy at Day 6 (Day $0=$ start of estrus). Of each embryo category, 50 morulae and 50 blastocysts were vitrified (Treatment group) while fresh morulae $(n=40)$ and blastocysts $(n=40)$ acted as control group. After one week of storage, vitrified embryos were cultured in vitrofor $24 \mathrm{~h}$ after warming. Non-vitrified morulae $(\mathrm{n}=40)$ and blastocysts $(n=40)$, cultured in vitro for $24 \mathrm{~h}$ were used as controls. After the in vitro culture period, embryo viability was morphologically assessed. A total of 30 viable embryos per group and embryonic stage(three pools of 10), were subjected to gene expressionanalysis byusing a microarray approach. A fold change cut-off of \pm 1.5 and a p-unadjusted $<0.05$ were used to distinguish differentially expressed genes (DEGs). The survival rates of vitrified/warmed morulae and blastocysts were similar to those of the control (nearly $100 \%$, n.s.).A total of 233 DEGs were identified in vitrified morulae (38 upregulated and 195 downregulated) and 105 (112 upregulated and 93 downregulated) in vitrified blastocysts compared to the control group.Transcriptome DEG profiles were dependent on developmental stage, and GO enrichment analysis mainly related DEGs tobiological processes. The vitrification/warming impact on morulae was mostly repression of gene expression with the exception of metabolism-related pathways. In the case of blastocysts, we noted the activation of the cell cycle, cellular senescence andof signaling pathways for TFG $\beta, p 53$, FoxO and MAPK. Disruption of metabolic-related pathways in morulae and steroid biosynthesis and gap junctions in blastocysts could be related to impaired embryo quality and developmental potential, despite the rather high post-warming survival rates seen in vitro.

\section{Conclusion}

In conclusion, vitrification modified the transcriptome of in vivo-derived porcine morulae and blastocysts, resulting in moderate gene expression changes, which may disturb subsequent embryo development and pregnancy after embryo transfer.

\section{Background}

Cryopreservation[1-3] of porcine embryos has essential applications for agriculture and biomedical research, since it is the best way to store valuable genetic material (reviewed in [4, 5]). Pig embryos have been challenging to cryopreserve due to their high amount of cytoplasmic lipids, which results in extreme chilling sensitivity [6], but significant advances have been made for this technique, thanks to the 
development of vitrification protocols (reviewed in [5, 7-10]). The implementation of vitrification protocols, particularly the open pulled straw (OPS) system [11] using superfine OPS (SOPS; [12] straws, has provided excellent viability in vitro reaching $>80 \%$ with vitrified morulae and $>90 \%$ ) in blastocysts [13]; further, encouraging farrowing rates (range: 38.9-75\%) have been achieved after nonsurgical [13-15] and surgical $[15,16]$ transfer of vitrified morulae and blastocysts. However, although the published reports are few, pregnancy we have observed a higher pregnancy loss for vitrified embryos (10-20\%) than that of fresh embryos (<2.5\%) [17]. The mechanisms underlying this observation are unknown. Currently, we know several factors affecting the vitrification of porcine embryos, such as the embryo donor $[3,18]$, the embryo developmental stage $[2,3,13]$ or the concentration of cryoprotectants [1]. We also know that, vitrification negatively impacts porcine embryo quality, augmenting levels of apoptosis $[19,20]$ or impairing ultrastructure [21]. Vitrification has been found to cause modifications in the embryo gene expression in several species [22-27]; however, the consequences of vitrification on gene expression of mammalian embryos are poorly known.

General transcriptome experiments of vitrified-warmed have been done only in bovine. Vitrification of in vitro-produced (IVP) bovine embryos caused overexpression of apoptosis-related genes [25] and the repression of genes involved in cell differentiation, cell adhesion and metabolism of lipids [28]. It has been also demonstrated that vitrification modified expression of genes related to stress response [29] in both IVP and in vivo-derived bovine blastocysts. Comparative studies on porcine are very scarce and limited to IVP embryos. Research based on qRT-PCR has demonstrated that vitrification significantly upregulates genes involved in both mitochondria and death receptor-mediated apoptotic pathways in porcine parthenogenic blastocysts [22]. It has also been reported that vitrification causes the downregulation of POU5F1, which is related to embryo implantation [30], the upregulation of HSPA1A, which is involved in stress regulation [30], vitrification also the modifies expression levels of IGF2 and IGF2R imprinted genes [23] in IVP-produced porcine blastocysts. Although these studies are useful, they are focused on few selected genes and therefore the information about the vitrification impact on the embryo transcriptome is very limited. A better knowledge of the overall vitrification effects on the embryonic transcriptome may help to understand sublethal cryoinjuries that could be associated with embryo developmental and pregnancy failure and it would yield new awareness about the response mechanisms of embryos undergoing vitrification. Such studies should be done on in vivo-derived porcine embryos, which are the only embryos currently suitable for commercial embryo transfer in this species.

Microarrays or RNA-Seq analysis are the most efficient and comprehensive technologies to provide a whole-transcriptome coverage [31], enabling assessment of the expression of thousands of genes with a single experiment. Therefore, this study used a microarray approach with qRT-PCR confirmation to investigate the effect of vitrification on the gene expression patterns of in vivo-derived porcine embryos at the morula and blastocyst stages, to determine if sub-lethal modifications, escaping conventional morphology screening of embryo viability, are caused by the procedure.

\section{Materials And Methods}




\subsection{Chemicals}

Chemicals and media were acquired from Sigma-Aldrich Química S.A. (Madrid, Spain) unless otherwise indicated.

\subsection{Animals}

Embryos were obtained from hybrid donor sows (Landrace $x$ Large-White) from the same genetic line (2 to 6 parities) located at a commercial farm (Agropor S.A., Murcia, Spain) and were maintained under field conditions, and placed individually in crates in a mechanically ventilated confinement facility. The sows were fed a commercial ration twice daily according to their nutritional requirements, with constant access to water.

\subsection{Detection of estrus and artificial insemination}

Weaning was used to synchronize the estrus of the sows. Sows were evaluated for estrus once a day (at 7:00 a.m.) beginning the day after weaning. Sows were exposed to a vasectomized mature boar allowing snout-to-snout contact and considered in estrus when they showed a standing estrus reflex when applying manual back pressure. Only sows with an interval between weaning and estrus of 4 to 5 days were used as embryo donors. Estrus sows were artificially inseminated post-cervically at 6 and $24 \mathrm{~h}$ after the onset of estrus. Insemination doses ( $45 \mathrm{~mL}$ containing $1.5 \times 10^{9}$ spermatozoa) were prepared in a commercial artificial insemination center with ejaculates extended in Beltsville Thawing Solution extender (BTS; [32]. Sperm doses were stored at $17^{\circ} \mathrm{C}$ for a maximum period of $24 \mathrm{~h}$.

\subsection{Embryo recovery and assessment}

Morulae and blastocysts were surgically collected from the donor sows on Day 6 of the estrus cycle, with Day 0 being considered the onset of estrus. $\square$ Sedation of embryo donors was performed with azaperone (Stresnil ${ }^{\circledR}$, Landegger Strasse, Austria; $2 \mathrm{mg} / \mathrm{kg}$ body weight, i.m.) and general anesthesia was induced with sodium thiopental (B.Braun VetCare SA, Barcelona, Spain; $7 \mathrm{mg} / \mathrm{kg}$ body weight, i.v) and was maintained with $3-5 \%$ isoflurane gas (IsoFlo®, Madrid, Spain). The genital tract was exposed by performing a mid-ventral laparotomy. Then, the corpora lutea present in each ovary were counted and embryos were collected as previously described [33] by flushing the tip of each uterine horn with $30 \mathrm{~mL}$ of Tyrode's lactate (TL)-HEPES- polyvinyl alcohol [34] with some modifications (TL-HESPES-PVA; [15]. After flushing, the embryos collected from the uterine horn were evaluated under a stereomicroscope at a $60 \mathrm{x}$ magnification, and the developmental stage and quality were assessed. One-cell structures and poorly developed embryos were classified as oocytes and degenerated embryos, respectively. Only morulae and unhatched full blastocysts with good or excellent morphology according to the criteria of the International Embryo Transfer Society [35] and an intact zona pellucida were selected for the experiments. Collected embryos were washed three times in TL-HEPES-PVA, placed Eppendorf tubes containing $1.5 \mathrm{~mL}$ of this medium and transported to the University of Murcia (Spain) in a transportable incubator set at $39^{\circ} \mathrm{C}$ within $2 \mathrm{~h}$ after collection.

\subsection{Vitrification and warming}


Vitrification and warming were performed according to a previously described protocol [16] in 4-well tissue culture plates (Nunc A/C, Roskilde, Denmark). The basic medium (BM) for vitrification and warming was TL-HEPES-PVA and all media were held at $39^{\circ} \mathrm{C}$. Morulae and blastocysts were vitrified separately in groups of 4 to 6 embryos within $4 \mathrm{~h}$ of embryo collection. Embryos were washed twice in $\mathrm{BM}$ at $39{ }^{\circ} \mathrm{C}$ and were subsequently equilibrated in BM containing $7.5 \%(\mathrm{v} / \mathrm{v})$ dimethyl sulfoxide and $7.5 \%$ $(\mathrm{v} / \mathrm{v})$ ethylene glycol for 3 min; then, they were treated with BM supplemented with $16 \%(\mathrm{v} / \mathrm{v})$ dimethyl sulfoxide, $16 \%(\mathrm{v} / \mathrm{v})$ ethylene glycol and $0.4 \mathrm{M}$ sucrose, for $1 \mathrm{~min}$. After the last equilibration, embryos were located in a $1.5 \mu \mathrm{L}$ drop and loaded into the narrow end of a superfine open pulled straw (SOPS; Minitüb, Tiefenbach, Germany) by capillary action. Immediately, the straw containing the embryos was plunged horizontally into liquid nitrogen. After one week of storage in liquid nitrogen, embryos were warmed by the one-step dilution method (Cuello et al., 2004; Sanchez-Osorio et al., 2008a). Briefly, the straw containing the embryos were removed from de liquid nitrogen and wasimmediately (less than one second) vertically submerged in a well containing $1 \mathrm{~mL}$ of BM supplemented with $0.13 \mathrm{M}$ sucrose and equilibrated in this medium for 5 min. Finally, embryos were washed in BM and then cultured in vitro for $24 \mathrm{~h}$.

\subsection{In vitro embryo culture and evaluation of in vitro embryo viability postwarming}

Post-warmed morulae and blastocysts were cultured in 4-well tissue culture plates; each well contained $500 \mu \mathrm{L}$ per well of NCSU-23 [38] culture medium supplemented with $0.4 \mathrm{mg} / \mathrm{mL}$ of bovine serum albumin (BSA) and 10\% (v/v) fetal calf serum, which was under paraffin oil (NidoilTM, Nidacon, Mölndal, Sweden) overlay (Martinez et al., 2017). Embryo culture was performed in an incubator at $38.5^{\circ} \mathrm{C}$ with $5 \% \mathrm{CO}_{2}$ in air and $97 \%$ humidity atmosphere. After $24 \mathrm{~h}$ of in vitro culture, embryo morphology was assessed by stereomicroscopy to determine embryo viability and embryo developmental stage. The vitrified-warmed morulae that had developed to the blastocyst stage and the vitrified-warmed blastocysts that restructured their blastocoelic cavities after $24 \mathrm{~h}$ of in vitro culture and exhibited an excellent or good appearance were considered viable. Fresh control embryos that progressed after in vitro culture and showed good or excellent morphological features were classified as viable. The survival rate was calculated as the ratio of viable embryos to the total number of cultured embryos.

\subsection{Sample preparation and microarray hybridization}

Total RNA was extracted from embryo samples was performed with an RNeasy Micro kit (P/N 74004; Qiagen Iberica, Madrid, Spain) according to manufacturer instructions. The isolated RNA was checked with a Nanodrop 2000 (ThermoFisher Scientific, Madrid, Spain) and a Bioanalyzer 2100 (Agilent, Santa Clara, CA, USA) to determine the total RNA amount and quality. The RNA integrity (RIN) values obtained ranged from 8 to 10. Then, ss-cDNA was synthesized from $650 \mathrm{pg}$ of RNA from each sample using a GeneChip 3’ IVT Pico Reagent kit (P/N 902790; Affymetrix, ThermoFisher Scientific, Madrid Spain), according to the protocol supplied by the manufacturer. The amount and quality of ds-cDNA was assessed by a Nanodrop 2000 (ThermoFisher Scientific, Madrid, Spain) and a Bioanalyzer 2100 (Agilent, Santa Clara, CA, USA); ds-DNA targets were cleaned, and after fragmentation and terminal labelling, 
$4.5 \mu \mathrm{g}$ of fragmented and biotinylated ds-DNA were added to a hybridization mix from a GeneChip Hybridization, Wash and Stain kit (P/N 90720; Affymetrix) according to the recommendations of the manufacturer. The resulting preparations were hybridized to the GeneChip ${ }^{\circledR}$ Porcine Genome Array (P/N 900624; Affymetrix), which assesses 23,256 transcripts corresponding to 20,201 genes and provides widespread coverage of the Sus scrofa transcriptome. After scanning the array, microarray data were processed using the Affymetrix Expression Command Console (Affymetrix), and all samples met the quality criteria.

\subsection{Microarray data analysis}

The robust multiarray average (RMA) method was used to normalize the intensity data of each GeneChip ${ }^{\circledR}$ array [39], processing average intensity values according to the background adjustment. Raw values were then $\log _{2}$ transformed, and quantile normalized in order to get a single intensity value for each probe set. Partek Genomics Suite and Partek Pathways software (Partek Incorporated, St. Louis, USA) were used for the statistical analysis and biological interpretation of data. Principal component analysis (PCA) was used to provide the general configuration of the evaluated dataset and to observe variations in the transcriptome between samples. Statistical analysis was based on tsingle-factor ANOVA with a restrictive threshold at an unadjusted $P$ value lower than 0.05 for selecting differentially expressed genes (DEGs). The analysis of the overrepresented Gene Ontology (GO) terms and pathways were analyzed based on the Kyoto Encyclopedia of Genes and Genomes (KEGG) database. Pathway networks were constructed using ClueGo v2.0.3 application from the Cytoscape v3.0.0 [40]. The ClueGo ontology source was KEGG pathway database. Pathways were functionally grouped based kappa score $(\geq 0.4)$. The following criteria were used for the ClueGo analysis: GO tree levels, 2-5 (first level = 0); minimum number of genes, 2; minimum percentage of genes, 2; $\mathrm{GO}$ term fusion; $\mathrm{GO}$ term grouping, initial group size of 2 and $50 \%$ for group merge.

\subsection{Quantitative real-time PCR (qRT-PCR) analysis}

For qRT-PCR we analyzed total RNA from the same samples used for the microarrays that was reversetranscribed to generate $\mathrm{CDNA}$ using a Maxima $\mathrm{H}$ Minus First Strand CDNA Synthesis Kit (Thermo Fisher Scientific); conditions were $25^{\circ} \mathrm{C}$ for $10 \mathrm{~min}, 50^{\circ} \mathrm{C}$ for $15 \mathrm{~min}$ and $85^{\circ} \mathrm{C}$ for $5 \mathrm{~min}$. Primers were designed using Primer Express ${ }^{\mathrm{TM}}$ software v3.0.1 (Applied Biosystems, Foster City, CA, USA) and were commercially synthesized (primer sequences are shown in Table 1). The qRT-PCRs were performed with iTaqTM Universal SYBR Green Supermix in 10- $\mu \mathrm{L}$ volumes with $500 \mathrm{nM}$ of each set of primers. All reactions were carried out in a QuantStudio ${ }^{\mathrm{Tm}} 5$ Real-Time PCR System (Applied Biosystems). The thermal cycling profile was $50^{\circ} \mathrm{C}$ for $2 \mathrm{~min}$ for uracil-DNA glycosylase activation, $95^{\circ} \mathrm{C}$ for $10 \mathrm{~min}$ for initial denaturation followed by 40 cycles of $95^{\circ} \mathrm{C}$ for $15 \mathrm{~s}$ and $60^{\circ} \mathrm{C}$ for $1 \mathrm{~min}$. Melt curve analysis was carried out to evaluate the specificity of each PCR by detection of one single peak on the dissociation curve profile. A previous test with extra samples was conducted to calculate each primer pair efficiency according to the equation $E=10^{(-1 / \text { slope })}$. qRT-PCRs were run in triplicate per gene and per sample, and relative mRNA levels were quantified according to the Pfaffl method [41]. For data normalization, peptidylprolyl isomerase A (PPIA) was chosen as the housekeeping reference gene based on the results reported 
previously [42]. Gene efficiencies were calculated according to the equation $E=10^{(-1 / \mathrm{slope})}$. The qRT-PCR data were analyzed by Student's t-test using the IBM SPSS 24.0 Statistics package (IBM, Chicago, IL, USA). A p-value of $<0.05$ was considered statistically significant. 
Table 1

Sequences of the primers used for quantitative real-time PCR (qRT-PCR) analysis.

\begin{tabular}{|c|c|c|c|c|c|}
\hline $\begin{array}{l}\text { Gene } \\
\text { Symbol }\end{array}$ & $\begin{array}{l}\text { Accession } \\
\text { number }\end{array}$ & Primer & & Size & Efficiency \\
\hline \multirow[t]{2}{*}{ DECR1 } & \multirow[t]{2}{*}{ NM_001190232.2 } & $\begin{array}{l}\text { Forward } \\
\left(3^{\prime}-5^{\prime}\right)\end{array}$ & GCAATTCAGTGTGATGTGAGG & \multirow[t]{2}{*}{155} & \multirow[t]{2}{*}{92.85} \\
\hline & & $\begin{array}{l}\text { Reverse } \\
\left(5^{\prime}-3^{\prime}\right)\end{array}$ & ATGGTCTTCCAGGCATTAGG & & \\
\hline \multirow[t]{2}{*}{ PAIP1 } & \multirow[t]{2}{*}{ XM_003483818.4 } & $\begin{array}{l}\text { Forward } \\
\left(3^{\prime}-5^{\prime}\right)\end{array}$ & AATGCCCCTGAATTTTACCC & \multirow[t]{2}{*}{192} & \multirow[t]{2}{*}{92.95} \\
\hline & & $\begin{array}{l}\text { Reverse } \\
\left(5^{\prime}-3^{\prime}\right)\end{array}$ & ATCTGTTGTAACCCAGCCATTT & & \\
\hline \multirow[t]{2}{*}{$M Y C$} & \multirow[t]{2}{*}{ NM_001005154.1 } & $\begin{array}{l}\text { Forward } \\
\left(3^{\prime}-5^{\prime}\right)\end{array}$ & TCGGACTCTCTGCTCTCCTC & \multirow[t]{2}{*}{157} & \multirow[t]{2}{*}{102.05} \\
\hline & & $\begin{array}{l}\text { Reverse } \\
\left(5^{\prime}-3^{\prime}\right)\end{array}$ & GCTGCCTCTTTTCCACAGAA & & \\
\hline \multirow[t]{2}{*}{ TP53INP1 } & \multirow[t]{2}{*}{ XM_001925224 } & $\begin{array}{l}\text { Forward } \\
\left(3^{\prime}-5^{\prime}\right)\end{array}$ & GCTGCCTCTTTTCCACAGAA & \multirow[t]{2}{*}{184} & \multirow[t]{2}{*}{91.44} \\
\hline & & $\begin{array}{l}\text { Reverse } \\
\left(5^{\prime}-3^{\prime}\right)\end{array}$ & TAAGATTTTGGCGACGAAGG & & \\
\hline \multirow[t]{2}{*}{ MGMT } & \multirow[t]{2}{*}{ XM_005671579.3 } & $\begin{array}{l}\text { Forward } \\
\left(3^{\prime}-5^{\prime}\right)\end{array}$ & GGTCCAGAGGAGATGATGGA & \multirow[t]{2}{*}{208} & \multirow[t]{2}{*}{94.23} \\
\hline & & $\begin{array}{l}\text { Reverse } \\
\left(5^{\prime}-3^{\prime}\right)\end{array}$ & GGGCTGCTAACTGCTGGTAA & & \\
\hline \multirow[t]{2}{*}{$D K K 3$} & \multirow[t]{2}{*}{ XM_005661123.3 } & $\begin{array}{l}\text { Forward } \\
\left(3^{\prime}-5^{\prime}\right)\end{array}$ & AAGACACGCAGCACAAACTG & \multirow[t]{2}{*}{163} & \multirow[t]{2}{*}{84.56} \\
\hline & & $\begin{array}{l}\text { Reverse } \\
\left(5^{\prime}-3^{\prime}\right)\end{array}$ & AAGACACGCAGCACAAACTG & & \\
\hline \multirow[t]{2}{*}{ WDR35 } & \multirow[t]{2}{*}{ XM_021087810.1 } & $\begin{array}{l}\text { Forward } \\
\left(3^{\prime}-5^{\prime}\right)\end{array}$ & AAGACACGCAGCACAAACTG & \multirow[t]{2}{*}{185} & \multirow[t]{2}{*}{85.46} \\
\hline & & $\begin{array}{l}\text { Reverse } \\
\left(5^{\prime}-3^{\prime}\right)\end{array}$ & AGAAGTCTGAATGGGTTCCTCA & & \\
\hline \multirow[t]{2}{*}{ PLEKHB1 } & \multirow[t]{2}{*}{ XM_005667095.3 } & $\begin{array}{l}\text { Forward } \\
\left(3^{\prime}-5^{\prime}\right)\end{array}$ & GAATTGGTTCGCCCTGTG & \multirow[t]{2}{*}{173} & \multirow[t]{2}{*}{114,3} \\
\hline & & $\begin{array}{l}\text { Reverse } \\
\left(5^{\prime}-3^{\prime}\right)\end{array}$ & GAATTGGTTCGCCCTGTG & & \\
\hline PPIA* & XM_021078519.1 & $\begin{array}{l}\text { Forward } \\
\left(3^{\prime}-5^{\prime}\right)\end{array}$ & AGAAGTCTGAATGGGTTCCTCA & 100 & 98.12 \\
\hline * & ene & & & & \\
\hline
\end{tabular}




\begin{tabular}{|llll|}
\hline $\begin{array}{l}\text { Gene } \\
\text { Symbol }\end{array}$ & $\begin{array}{l}\text { Accession } \\
\text { number }\end{array}$ & Primer & Size Efficiency \\
\hline & $\begin{array}{l}\text { Reverse } \\
\left(5^{\prime}-3^{\prime}\right)\end{array}$ & CCAACCACTCAGTCTTGGCA & \\
\hline *Housekeeping gene & & & \\
\hline
\end{tabular}

\subsection{Experimental design}

To evaluate the effects of vitrification on the transcriptome of porcine in vivo-produced morulae and blastocysts, 13 weaned sows were used as embryo donors in three replicates. A total of 50 morulae and 50 blastocysts were vitrified and warmed, and then they were cultured in vitro for $24 \mathrm{~h}$. Control embryos were fresh morulae $(n=40)$ and blastocysts $(n=40)$ cultured in vitro for $24 h$. After in vitro culture, the viability of vitrified-warmed and control embryos was assessed, and survival rates were calculated. Three pools of 10 viable embryos each were prepared from each experimental group (vitrified and control) and each embryonic developmental stage (morulae and blastocysts). Embryos were placed in $5 \mu \mathrm{L}$ Phosphate-buffered saline (PBS) in RNAase free Eppendorf tubes and then stored at $-80^{\circ} \mathrm{C}$ until transcriptome analysis. A total of 8 genes ( 5 upregulated genes and 3 downregulated genes according to the microarray results; Table 1) were selected to confirm microarray results by qRT-PCR. For this validation, three biological replicates and three technical replicates per sample were performed.

\section{Results}

\subsection{Embryo collection and embryo viability}

The mean ovulation rate of donor sows was $20.8 \pm 3.6$ corpora lutea (range 14 to 25 ), and the recovery rate was $92.2 \%$. Of the recovered structures, $96.0 \%$ were embryos, and the rest were unfertilized oocytes and/or degenerated embryos. The total number of embryos collected was 239 , of which $42.3 \%, 54.8 \%$ and $2.9 \%$ were morulae, blastocysts and hatched blastocysts, respectively. A total of 90 morulae and 90 blastocysts were selected for use in this study, and the remaining embryos were used in other experiments. The survival rates of vitrified-warmed morulae $(92.0 \pm 3.3 \%)$ and blastocysts $(96.1 \pm 3.4)$ were similar (n.s.) to each other and to those obtained in control embryos (100\%).

\subsection{Transcriptome profiles of vitrified-warmed morulae and blastocysts}

Vitrification and warming affected the transcriptome profile of porcine morulae and blastocysts. The PCA revealed that for $71.0 \%$ and $68.8 \%$ of variance was explained by the treatment (vitrification or not) of morulae and blastocysts, respectively. First, lists of the differentially expressed transcripts were generated using an unadjusted $p$-value of 0.05 and various fold change cutoff values (Fig. 1).

Subsequent analyses were performed using the DEGs list produced from the selection criterion of fold change $<-1.5$ and $>1.5$. Using these parameters, 233 DEGs were identified in vitrified morulae compared 
to the control group. More specifically, 38 genes were upregulated, whereas 195 were downregulated (Fig. 1). With regard to the blastocysts, the number of DEGs was 205. Interestingly, the proportion of upregulated genes (112) was higher than it was in the morulae (Fig. 1). The DEGs detected in vitrified morulae and blastocysts are represented in the Volcano plots (Fig. 1). The unsupervised hierarchical clustering of transcriptome samples revealed that morulae and blastocysts vitrified samples could be clearly distinguished from the control samples (Fig. 2). The transcriptome profiles obtained for vitrified morulae and blastocysts were very different. Analysis of DEGs in vitrified morulae and blastocysts showed that only 3 upregulated and 8 downregulated DEGs were shared between vitrified morulae and blastocysts (Fig. 3).

\subsection{Gene Ontology (GO) enrichment analysis of DEGs in vitrified morulae and blastocysts}

Gene ontology (GO) analysis identified the main biological processes targeted by the DEGs. A total of 105 and 671 enriched GO terms with an enrichment score $\geq 3$ and an enrichment $p$-value $<0.05$ were detected for vitrified morulae and blastocysts, respectively. DThe most enriched GO terms for both developmental stages were related to biological process. Tables 2 and 3 summarize the top 10 most enriched GO terms corresponding to vitrified morula and blastocysts, respectively. 
Table 2

Top ten most significant gene ontology (GO) terms for the differentially expressed genes in vitrified morulae.

\begin{tabular}{|c|c|c|c|c|}
\hline BIOLOGICAL FUNCTION & TYPE & $\begin{array}{l}\text { Enrichment } \\
\text { Score }\end{array}$ & $\begin{array}{l}\text { Enrichment } \\
\text { p-value }\end{array}$ & $\begin{array}{l}\% \text { genes in group } \\
\text { that are present* }\end{array}$ \\
\hline Response to zinc ion & BP & 10.2 & 3.70E-05 & 75 \\
\hline $\begin{array}{l}\text { Long-chain fatty-acyl-CoA biosynthetic } \\
\text { process }\end{array}$ & BP & 6.6 & 0.0013 & 66.7 \\
\hline Cellular response to fatty acid & BP & 6.3 & 0.0018 & 25 \\
\hline $\begin{array}{l}\text { 3-oxo-arachidoyl (cerotoyl and } \\
\text { lignoceronnyl)-CoA synthase activity }\end{array}$ & MF & 5.9 & 0.0026 & 50 \\
\hline $\begin{array}{l}\text { Very-long-chain 3-ketoacyl-CoA synthase } \\
\text { activity }\end{array}$ & MF & 5.9 & 0.0026 & 50 \\
\hline $\begin{array}{l}\text { Long-chain fatty-acyl-CoA metabolic } \\
\text { process }\end{array}$ & $\mathrm{BP}$ & 5.9 & 0.0026 & 50 \\
\hline Fatty-acyl-CoA biosynthetic process & $\mathrm{BP}$ & 5.9 & 0.0026 & 50 \\
\hline $\begin{array}{l}\text { Rab guanyl-nucleotide exchange factor } \\
\text { activity }\end{array}$ & MF & 5.9 & 0.0026 & 50 \\
\hline Response to fatty acid & $\mathrm{BP}$ & 5.8 & 0.0029 & 21.4 \\
\hline Lysosome organization & $\mathrm{BP}$ & 5.3 & 0.0051 & 17.7 \\
\hline
\end{tabular}


Table 3

Top ten most significant gene ontology (GO) terms for the differentially expressed genes in vitrified blastocysts.

\begin{tabular}{|c|c|c|c|c|}
\hline BIOLOGICAL FUNCTION & TYPE & $\begin{array}{l}\text { Enrichment } \\
\text { Score }\end{array}$ & $\begin{array}{l}\text { Enrichment } \\
\text { p-value }\end{array}$ & $\begin{array}{l}\% \text { genes in } \\
\text { group that are } \\
\text { present* }\end{array}$ \\
\hline $\begin{array}{l}\text { Protein kinase } \mathrm{C} \text {-activating } \mathrm{G} \text { protein- } \\
\text { coupled receptor signalling pathway }\end{array}$ & $\mathrm{BP}$ & 8.1 & 0.0003 & 37.5 \\
\hline ATPase regulator activity & MF & 7.7 & 0.0004 & 33.3 \\
\hline Glucose transmembrane transport & $\mathrm{BP}$ & 7.4 & 0.0006 & 30 \\
\hline Muscle cell cellular homeostasis & $\mathrm{BP}$ & 7.1 & 0.0008 & 27.3 \\
\hline Hexose transmembrane transport & $\mathrm{BP}$ & 7.1 & 0.0008 & 27.3 \\
\hline $\begin{array}{l}\text { Positive regulation of smooth muscle cell } \\
\text { chemotaxis }\end{array}$ & $\mathrm{BP}$ & 6.9 & 0.0010 & 66.7 \\
\hline Monosaccharide transmembrane transport & $\mathrm{BP}$ & 6.6 & 0.0014 & 23.1 \\
\hline Manganese ion transport & $\mathrm{BP}$ & 6.3 & 0.0019 & 50 \\
\hline Manganese ion transmembrane transport & $\mathrm{BP}$ & 6.3 & 0.0019 & 50 \\
\hline Hexose transmembrane transporter activity & MF & 6.3 & 0.0019 & 50 \\
\hline
\end{tabular}

All DEGs in vitrified morulae and blastocysts were classified within different functional categories based on molecular function (Fig. 4A and 4A'), biological process (Fig. 4B and 4B') and cellular component (Fig. $4 \mathrm{C}$ and $4 \mathrm{C}^{\prime}$ ). Within each of the GO terms represented, vitrified morulae displayed a higher proportion of downregulated DEGs than vitrified blastocysts.

\subsection{KEGG Pathway enrichment analysis of DEGs in vitrified morulae and blastocysts}

Pathway enrichment analysis of DEGs in vitrified morulae detected ten enriched KEGG pathways for upregulated (Table 4) and seven for downregulated DEGs (Table 5). Enriched pathways for upregulated genes in morulae were mainly metabolism-related pathways. The most enriched pathways related to downregulated DEGs in morulae were glycolysis-gluconeogenesis and protein export. 
Table 4

Enrichment analysis of pathways for up-regulated differentially expressed genes in vitrified morulae.

\begin{tabular}{|c|c|c|c|c|c|}
\hline Pathway Name & Pathway ID & $\begin{array}{l}\text { Enrichment } \\
\text { Score }\end{array}$ & $\begin{array}{l}\text { Enrichment } \\
\text { p-value }\end{array}$ & $\begin{array}{l}\% \text { genes } \\
\text { of DEGs } \\
\text { in } \\
\text { pathway }\end{array}$ & Gene list \\
\hline $\begin{array}{l}\text { Glycosaminoglycan } \\
\text { degradation }\end{array}$ & kegg_pathway_48 & 7.6 & 0.0005 & 11.1 & $\begin{array}{l}\text { HEXA, } \\
\text { SPAM1 }\end{array}$ \\
\hline Tryptophan metabolism & kegg_pathway_31 & 5.9 & 0.0029 & 4.7 & $\begin{array}{l}\text { ACAT2, } \\
\text { HAAO }\end{array}$ \\
\hline Metabolic pathways & kegg_pathway_87 & 5.5 & 0.0039 & 0.7 & $\begin{array}{l}\text { ACAT2, } \\
\text { HAAO, } \\
\text { HEXA, } \\
\text { MAN1C1, } \\
\text { PIP5K1A, } \\
\text { PYGM, } \\
\text { SPAM1 }\end{array}$ \\
\hline $\begin{array}{l}\text { Synthesis and } \\
\text { degradation of ketone } \\
\text { bodies }\end{array}$ & kegg_pathway_11 & 4.1 & 0.0168 & 11.1 & ACAT2 \\
\hline $\begin{array}{l}\text { Glycosphingolipid } \\
\text { biosynthesis - ganglio } \\
\text { series }\end{array}$ & kegg_pathway_63 & 3.6 & 0.0279 & 6.7 & HEXA \\
\hline $\begin{array}{l}\text { Glycosphingolipid } \\
\text { biosynthesis - globo and } \\
\text { isoglobo series }\end{array}$ & kegg_pathway_62 & 3.5 & 0.0298 & 6.3 & HEXA \\
\hline Other glycan degradation & kegg_pathway_42 & 3.4 & 0.0334 & 5.6 & HEXA \\
\hline $\begin{array}{l}\text { Terpenoid backbone } \\
\text { biosynthesis }\end{array}$ & kegg_pathway_79 & 3.3 & 0.0389 & 4.8 & ACAT2 \\
\hline Butanoate metabolism & kegg_pathway_67 & 3.1 & 0.0443 & 4.2 & ACAT2 \\
\hline Fatty acid elongation & kegg_pathway_9 & 3.1 & 0.0461 & 4.0 & ELOVL1 \\
\hline
\end{tabular}


Table 5

Enrichment analysis of pathways for down-regulated differentially expressed genes in vitrified morulae

\begin{tabular}{|c|c|c|c|c|c|}
\hline Pathway Name & Pathway ID & $\begin{array}{l}\text { Enrichment } \\
\text { Score }\end{array}$ & $\begin{array}{l}\text { Enrichment } \\
\text { p-value }\end{array}$ & $\begin{array}{l}\% \text { genes } \\
\text { of DEGs } \\
\text { in } \\
\text { pathway }\end{array}$ & Gene list \\
\hline $\begin{array}{l}\text { Glycolysis / } \\
\text { Gluconeogenesis }\end{array}$ & kegg_pathway_1 & 4.3 & 0.0141 & 11.1 & $\begin{array}{l}A K R 1 A 1, \\
A L D H 1 B 1, \\
A L D O B\end{array}$ \\
\hline Protein export & kegg_pathway_107 & 4.2 & 0.0150 & 4.7 & $\begin{array}{l}\text { SPCS3, } \\
\text { SRP72 }\end{array}$ \\
\hline $\begin{array}{l}\text { Fatty acid } \\
\text { elongation }\end{array}$ & kegg_pathway_9 & 4.0 & 0.0176 & 0.6 & $\begin{array}{l}\text { ELOVL7, } \\
\text { HACD4 }\end{array}$ \\
\hline Spliceosome & kegg_pathway_105 & 4.0 & 0.0181 & 11.1 & $\begin{array}{l}\text { HSPA2, } \\
\text { RBMX, } \\
\text { SNRNP40, } \\
\text { SRSF6 }\end{array}$ \\
\hline $\begin{array}{l}\text { Fructose and } \\
\text { mannose } \\
\text { metabolism }\end{array}$ & kegg_pathway_5 & 3.6 & 0.0281 & 6.7 & $\begin{array}{l}A L D O B \\
F P G T\end{array}$ \\
\hline $\begin{array}{l}\text { Wnt signaling } \\
\text { pathway }\end{array}$ & kegg_pathway_158 & 3.6 & 0.0282 & 6.3 & $\begin{array}{l}\text { GPC4, LRP6, } \\
\text { MAPK } 8 \\
P P P 3 C B\end{array}$ \\
\hline Endocytosis & kegg_pathway_142 & 3.1 & 0.0444 & 5.6 & $\begin{array}{l}\text { ARAP2, } \\
\text { ASP1, } \\
\text { HSPA2, } \\
\text { PARD6G, } \\
\text { TFRC }\end{array}$ \\
\hline
\end{tabular}

Partek detected a total of ten enriched pathways for upregulated DEGs in vitrified blastocysts (Table 6); the most enriched pathways in this group were TGF $\beta$, p53 and FoxO signaling pathways. Only four enriched pathways were obtained with downregulated DEGs (Table 7), including steroid biosynthesis, TGF $\beta$ and cGMP-PKG signaling pathways and gab junctions. Figure 5 represents the KEGG pathway networks analyzed with Cytoscape for vitrified morulae (Fig. 5A) and blastocysts (Fig. 5B). 
Table 6

Enrichment analysis of pathways for up-regulated genes in vitrified blastocysts

\begin{tabular}{|c|c|c|c|c|c|}
\hline Pathway Name & Pathway ID & $\begin{array}{l}\text { Enrichment } \\
\text { Score }\end{array}$ & $\begin{array}{l}\text { Enrichment } \\
\text { p-value }\end{array}$ & $\begin{array}{l}\% \text { genes } \\
\text { of DEGs } \\
\text { in } \\
\text { pathway }\end{array}$ & Gene list \\
\hline $\begin{array}{l}\text { TGF } \beta \text { signaling } \\
\text { pathway }\end{array}$ & kegg_pathway_161 & 6.7 & 0.0012 & 4.9 & $\begin{array}{l}\text { BMPR1B, } \\
\text { ID4, SMAD3, } \\
\text { TGFB1 }\end{array}$ \\
\hline $\begin{array}{l}\text { p53 signaling } \\
\text { pathway }\end{array}$ & kegg_pathway_133 & 5.1 & 0.0062 & 4.6 & $\begin{array}{l}\text { CDKN1A, } \\
\text { FAS, ZMAT3 }\end{array}$ \\
\hline $\begin{array}{l}\text { FoxO signaling } \\
\text { pathway }\end{array}$ & kegg_pathway_126 & 5.0 & 0.0065 & 3.1 & $\begin{array}{l}\text { CDKN1A, } \\
\text { GABARAPL 1, } \\
\text { SMAD3, } \\
\text { TGFB1 }\end{array}$ \\
\hline $\begin{array}{l}\text { Other types of O- } \\
\text { glycan biosynthesis }\end{array}$ & kegg_pathway_44 & 4.9 & 0.0077 & 8.7 & $\begin{array}{l}\text { B3GLCT, } \\
\text { ST6GAL } 1\end{array}$ \\
\hline Cellular senescence & kegg_pathway_154 & 4.4 & 0.0117 & 2.6 & $\begin{array}{l}\text { CDKN1A, } \\
\text { MAP2K6, } \\
\text { SMAD3, } \\
\text { TGFB1 }\end{array}$ \\
\hline $\begin{array}{l}\text { Glycerophospholipid } \\
\text { metabolism }\end{array}$ & kegg_pathway_55 & 4.1 & 0.0173 & 3.2 & $\begin{array}{l}\text { DGKA, } \\
\text { MBOAT1, } \\
\text { PLA2G16 }\end{array}$ \\
\hline $\begin{array}{l}\text { MAPK signaling } \\
\text { pathway }\end{array}$ & kegg_pathway_115 & 3.7 & 0.0238 & 1.8 & $\begin{array}{l}\text { DUSP6, FAS, } \\
\text { HSPB1, } \\
\text { MAP2K6, } \\
\text { TGFB1 }\end{array}$ \\
\hline Cell cycle & kegg_pathway_131 & 3.4 & 0.0324 & 2.5 & $\begin{array}{l}\text { CDKN1A, } \\
\text { SMAD3, } \\
\text { TGFB1 }\end{array}$ \\
\hline $\begin{array}{l}\text { Signaling pathways } \\
\text { regulating } \\
\text { pluripotency of stem } \\
\text { cells }\end{array}$ & kegg_pathway_174 & 3.2 & 0.0420 & 2.2 & $\begin{array}{l}\text { BMPR1B, } \\
\text { ID4, SMAD3 }\end{array}$ \\
\hline $\begin{array}{l}\text { Glycerolipid } \\
\text { metabolism }\end{array}$ & kegg_pathway_52 & 3.1 & 0.0455 & 3.4 & $\begin{array}{l}D G K A \\
M B O A T 1\end{array}$ \\
\hline
\end{tabular}


Table 7

Enrichment analysis of pathways for down-regulated genes in vitrified blastocysts

\begin{tabular}{|llllll|}
\hline Pathway Name & Pathway ID & $\begin{array}{l}\text { Enrichment } \\
\text { Score }\end{array}$ & $\begin{array}{l}\text { Enrichment } \\
\text { p-value }\end{array}$ & $\begin{array}{l}\text { \% genes of } \\
\text { DEGs in } \\
\text { pathway }\end{array}$ & Gene list \\
\hline $\begin{array}{l}\text { Steroid } \\
\text { biosynthesis }\end{array}$ & kegg_pathway_12 & 5.7 & 0.0035 & 10.5 & $\begin{array}{l}\text { DHCR24, } \\
\text { MSMO1 }\end{array}$ \\
\hline $\begin{array}{l}\text { TGF-beta } \\
\text { signaling pathway }\end{array}$ & kegg_pathway_161 & 5.0 & 0.0066 & 3.7 & $\begin{array}{l}\text { BAMBI, } \\
\text { MYC, } \\
\text { RBL1 }\end{array}$ \\
\hline $\begin{array}{l}\text { cGMP-PKG } \\
\text { signaling pathway }\end{array}$ & kegg_pathway_120 & 5.0 & 0.0067 & 2.5 & $\begin{array}{l}\text { AKT1, } \\
\text { ITPR1, } \\
\text { Gap junction }\end{array}$ \\
& kegg_pathway_173 & 4.9 & 0.0073 & 3.5 & $\begin{array}{l}\text { HTR2B, } \\
\text { ITPR1, } \\
\text { MAP3K2 }\end{array}$ \\
\hline
\end{tabular}

\subsection{Validation of microarray results}

Validation of microarray data was performed by qRT-PCR. The eight genes validated by qRT-PCR showed an expression trend that was similar to the results observed in the microarrays (Fig. 6). qRT-PCR analysis revealed that the mRNA levels for TP53INP, MGMT, DKK3 in blastocysts and WDR25 and PLEKHB1 in morulae were significantly $(\mathrm{p}<0.05)$ upregulated. The expression of PAIP1 in blastocysts and DECR1 in morulae was significantly $(p<0.05)$ downregulated. The qRT-PCR analysis revealed that the expression of $M Y C$ was consistent with the results of the microarray, but the difference in expression levels between vitrified and control blastocysts analyzed by qRT-PCR was not significant.

\section{Discussion}

To the best of our knowledge, this is the first report about the impact of vitrification/warming on the full transcriptome of in vivo-derived porcine morulae and blastocysts. This study contributes to the understanding of the consequences of vitrification/warming procedures on embryo quality and developmental competence, not only in pigs, but also in other mammalian species. Considering our results, the impact of vitrification in terms of the number of DEGs was similar for the morula (233 DEGs) and blastocysts (205 DEGs). Vitrification/warming caused moderate transcriptome changes in both, morulae and blastocysts, in terms of fold-changes. We only found eight DEGs in morulae and 6 in blastocysts showing a fold change greater than three. Although the number of DEGs and fold change values were similar for both developmental stages, vitrified morulae and blastocysts displayed very different transcriptome profiles, with only 12 (three upregulated and eight downregulated) DEGs in common. This is not surprising, considering that stage-specific gene expression between morulae and blastocysts is characteristic of the preimplantation embryo development [43]. 
The GO term enrichment analysis of DEGs in vitrified morulae revealed that, except for the biological process "reproduction", all the disturbed GO biological processes, GO cellular components and GO molecular functions were repressed. The most enriched GO terms in morulae were related to fatty acid and acyl-CoA metabolism. It is known that both fatty acids and acyl-CoA are metabolic switches linked to pluripotency that play an essential role in embryo development [44, 45]. In addition, acyl-CoA controls crucial cellular processes such as mitosis, autophagy and energy metabolism, and this control is either direct or is mediated by epigenetic regulation of gene expression [46, 47]. Fatty acids, on the other hand, are also key factors linked to metabolism, cell signaling, oxidative stress and gene expression in preimplantation embryos $([48,49]$. The downregulation of genes in these two functional groups may have deleterious effects on vitrified morulae development. It could be interesting to investigate whether supplementation of vitrification-warming medium with acyl-CoA and/or fatty acids may offset these effects.

For vitrified blastocysts, all DEGs involved in the GO biological process of growth, cell population proliferation, cell aggregation and detoxification GO biological processes and those related to antioxidant activity and protein folding chaperone $\mathrm{GO}$ molecular functions were upregulated. These results reflect that the vitrification/warming process induced a stress-related response in blastocysts. Among the upregulated DEGs, the following genes included in these categories, the TP53INP (tumor protein p53 inducible nuclear protein 1) and CDKN1A (cyclin-dependent kinase inhibitor 1A (p21, Cip 1) genes, are of special interest for their role in the regulation of cell death and survival under stress conditions $[50,51]$.

The KEGG pathway enrichment analysis of up- and downregulated genes of vitrified morulae and blastocysts showed that the impact of vitrification was moderate in terms of the number of pathways altered and the percentage of transcripts within each pathway that showed disturbed expression (range 0.7-11.1\%). Although, the disruption of gene expression can be considered moderate, we should pay particular attention to modified pathways that are crucial for embryo development. KEGG pathway analysis based on the upregulated DEGs in vitrified morulae, revealed that nine pathways were enriched. Genes upregulated in these pathways (HEXA, SPAM1, ACAT2, HAAO, MAN1C1, PIP5K1A, PYGM and $E L O V L 1)$ are not directly linked to embryo development. However, the enrichment of the metabolic pathways, which has also been described in vitrified in vivo-derived bovine blastocysts [50,51], could be sign of low embryo quality. The activation of metabolism-related pathways may cause detrimental effects on the development and implantation of vitrified morulae according to the "quiet embryo" hypothesis, which proposes that preimplantation embryo survival is associated with a relatively "quiet" level of metabolism (Baumann et al., 2007; Leese, 2002; Leese et al., 2007). Among the seven enriched pathways for downregulated genes in vitrified morulae, it is remarkably the Wnt signaling pathway that plays a critical role in embryo development [52-54]. The Wnt signaling pathway regulates cell proliferation and differentiation in mammalian embryos [55,56], and modified genes in this pathway were GPC4, LRP6, MAPK8 and PPP3CB. The repression of these genes may impair the developmental potential of vitrified morulae. 
Enriched pathways in vitrified blastocysts were different from those described for morulae because of the stage-specific gene expression described above [57-60]. Interestingly, when we examined enriched pathways for upregulated genes in vitrified blastocysts, we observed important biological processes (cellular senescence and cell cycle) and signaling pathways (TGF 3 , p53 and FoxO) that regulate the pluripotency of stem cells involved in embryo development and pregnancy. The enrichment of the TGF $\beta$ signaling pathway has also been reported in vitrified porcine COCs [44, 45], and upregulation of miRNAs related to this pathway was observed in vitrified mouse blastocysts [61]. The upregulated genes in the TGF $\beta$ signaling pathway were BMPR1B, ID4, SMAD3 and TGF $\beta 1$, and there were also DEGs involved in the cell cycle pathway (CDKN1A) and signaling pathways regulating the pluripotency of stem cells (BMPR1B, ID4 and SMAD3). These genes are key regulators of cell proliferation, stem-cell state, differentiation, and apoptosis at the earliest stages of embryo development [62] and the TGF $\beta 1$ and SMAD3 are also key factors during embryo implantation $[63,64]$. The activation of the TGF $\beta$-signaling pathway seems to be a response to cell stress and injury, as has been reported in epithelial cells [65]. The p53 signaling pathway is also an essential regulator of cellular stress, which may have opposite biological responses depending on many factors leading to cell death or cell survival [65]. The expression of TP53INP can be induced by many different stress signals [66] that have been described as consequences of embryo vitrification, such as oxidative stress $[67,68]$ or DNA damage $[19,69]$. In conditions of reparable damage or transient stress, TP53INP induces cell cycle arrest by increasing the expression of $C D K N 1 A / p 21[19,69]$, which was also upregulated in our vitrified blastocysts. This response is related to repair, protection, and adaptation, and ultimately to cell survival [51]. FoxO pathway is also activated under stress conditions [50, 70]; FoxO molecules have been described in the inner cell mass of mouse blastocysts [71], and the upregulate target genes, thereby promoting cell cycle arrest genes in order to keep cells away from stress. If the cell cycle arrest is not sufficient to recover cells, apoptosis is activated, thus producing cell death [71]. In addition, the cellular senescence and cell cycle pathways, which play essential roles in the cell response and cell repair under stressful conditions [71], were also enriched in the vitrified blastocysts. Our results show the triggering of essential repair mechanisms in the vitrified blastocysts, which has not been observed in the vitrified morulae. This fact could partly explain the vitrification of blastocyst being better than of morulae, which has been observed in some studies [72].

Interestingly, when analyzing the downregulated DEGs, TGF $\beta$-signaling pathway was enriched again; $B A M B I$ and $R B L 1$ are negative regulators of TGF $\beta$ and $M Y C$ encodes a nuclear phosphoprotein with a regulatory role [73]. Among the four enriched pathways obtained from the downregulated DEGs in vitrified blastocysts, the most remarkable is the steroid biosynthesis pathway. Historically, the production of steroids (estrogens) by porcine embryos has been considered the major signal for maternal recognition of pregnancy (Bazer et al., 1982). Recently, it has been demonstrated that although the production of embryonic estrogens is not essential for preimplantation development and early corpus luteum maintenance, it is indispensable for the maintenance of pregnancy beyond 30 days (Meyer et al., 2019). Therefore, the disruption of the steroid biosynthesis pathway could be, in part, responsible for the increased number of pregnancy failures that we have observed after transfer of vitrified blastocyst [17]. The enrichment of the Gap junction pathway that is involved in embryo-maternal interaction and 
implantation [77]. The HTR2B, which is a gene that belongs to this pathway, is involved in morphogenesis and development [73]; therefore, its repression could be detrimental for the embryo.

Comparing our results with previous results on the gene expression of vitrified porcine embryos performed by qRT-PCR, we observed very few matches due to the different origins of the embryos (parthenogenetic [78] or IVP [22]). Similar to Castillo-Martin et al. [23, 30], we detected the upregulation of an HSP gene (HSPB1) in vitrified blastocysts; HSPB1 encodes a small heat shock protein involved in the response to environmental stress [79]. This result again shows the response of vitrified blastocysts to vitrification-induced stress. Noteworthy is to consider that these sub-lethal modifications caused by the procedure of vitrification/waring, escaped our conventional morphological screening of embryo viability post-warming, which calls for a further screening of the extent of the transcriptomic alterations and their impact on embryo viability, and of the development of more refined methods to discover these modifications at warming.

\section{Conclusions}

Taken together, our results demonstrate that vitrification modified the transcriptome of in vivo-derived porcine morulae and blastocysts, resulting in different gene expression profiles based on the stage of development. The changes in gene expression that we observed could be considered moderate in terms of the number of DEGs and fold-change values. The vitrification impact on morulae consisted mostly of gene expression repression, except for metabolism related pathways. In the case of blastocysts, we noted the activation of the cell cycle, cellular senescence, TFG $\beta, p 53$, FoxO and MAPK signaling pathways in response to vitrification-induced stress. Disruption of pathways such as metabolic-related pathways in morulae, and steroid biosynthesis and gap junctions in blastocysts could be tightly related to the increased pregnancy loss observed after transfer of vitrified embryos. Further research is needed to increase the knowledge about the biological implications of the $\mathrm{GO}$ terms and pathways modified by vitrification procedures, as well as how to evolve screening methods for warmed embryos, beyond the apparently sub-optimal morphological evaluation currently used.

\section{Declarations}

\section{Ethics approval}

This investigation was accomplished following the Directive 2010/63/EU EEC for animal experimentation. The experiments were evaluated and approved in advance at the University of Murcia (Spain) by the Ethical Committee for Experimentation with Animals (research code: 486/2018).

\section{Consent for publication}

"Not applicable"

\section{Availability of data and materials}


The datasets used and/or analyzed during the current study are available from the corresponding author on reasonable request.

\section{Competing interests}

The authors declare no conflict of interest.

\section{Funding}

This research was funded by the Fundacion Seneca (19892/GERM/15), Murcia, Spain; the MICIU/FEDER (RTI2018-093525-B-I00), Madrid, Spain; the European Union's Horizon 2020 research and innovation program under the MSCA (grant agreement No 891663); and the Swedish Research Council FORMAS (Project 2017-00946), Stockholm, Sweden.

\section{Authors' contributions}

Conceptualization: C.C., C.A.M., M.A.G., H.R.-Mand E.A.M., methodology: C.C., C.A.M., J.M.C., I.P., M.A.G. and E.A.M.; software: C.C., C.A.M.and E.A.M., validation: E.A.M. and C.C.; data curation, E.A.M., writingoriginal draft preparation: C.C., C.A.M. and E.A.M, writing-review and editing: J.M.C, M.A.G., M.A-R. and H.R-M.visualization: C.C., supervision: C.C., E.A.M., M.A-R. and H.R-M., project administration, C.C and E.A.M.; funding acquisition, C.C., M.A.G., H.R.-M. and E.A.M. All authors have read and agreed to the published version of the manuscript.

\section{Acknowledgements}

To Dr. Maria J. Lopez, from the genomic service at University of Murcia, for expert assistance with the microarray analysis. To the staff of Agropor (Murcia, Spain) piggery for the excellent management of the animals. C.A.M. was supported by a postdoctoral grant from the Fundación Séneca, (Murcia, Spain; 20780/PD/18) and J.M.C. was supported by a pre-doctoral grant from the Ministry of Economy and Competitiveness (Madrid, Spain; BES-2016-077869).

\section{References}

1. Cuello C, Sanchez-Osorio J, Almiñana C, Gil MA, Perals ML, Lucas X, et al. Effect of the cryoprotectant concentration on the in vitro embryo development and cell proliferation of OPSvitrified porcine blastocysts. Cryobiology. 2008;56:189-94.

2. Cuello C, Gil MA, Parrilla I, Tornel J, Vázquez JM, Roca J, et al. Vitrification of porcine embryos at various developmental stages using different ultra-rapid cooling procedures. Theriogenology. 2004;62:353-61.

3. Sanchez-Osorio J, Cuello C, Gil MA, Almiñana C, Parrilla I, Caballero I, et al. Factors affecting the success rate of porcine embryo vitrification by the Open Pulled Straw method. Anim Reprod Sci. 2008;108:334-44. 
4. Dobrinsky JR. 11, 2001. Theriogenology. 2001;1333-44.

5. Martinez EA, Martinez CA, Cambra JM, Maside C, Lucas X, Vazquez JL, et al. Achievements and future perspectives of embryo transfer technology in pigs. Reprod Domest Anim. 2019;54:4-13.

6. Nagashima H, Kashiwazaki N, Ashman RJ, Grupen CG, Seamark RF, Nottle MB. Removal of Cytoplasmic Lipid Enhances the Tolerance of Porcine Embryos to Chilling. Biol Reprod. 1994;51:618-22.

7. Berthelot F, Martinat-Botté F, Vajta G, Terqui M. Cryopreservation of porcine embryos: State of the art. Livest Prod Sci. 2003;83:73-83.

8. Cameron RDA, Beebe LFS, Blackshaw AW. Cryopreservation and transfer of pig embryos. Soc Reprod Fertil Suppl. 2006;62:277-91.

9. Martinez EA, Vazquez JM, Roca J, Cuello C, Gil MA, Parrilla I, et al. An update on reproductive technologies with potential short-term application in pig production. Reprod Domest Anim. 2005;40:300-9.

10. Vajta G. Vitrification in human and domestic animal embryology: work in progress. Reprod Fertil Dev. 2013;25:719-27.

11. Vajta G, Holm P, Greve T, Callesen H. Vitrification of Porcine Embryos using the Open Pulled Straw (OPS) Method. Acta Vet Scand. 1997;38:349-52.

12. Isachenko V, Folch J, Isachenko E, Nawroth F, Krivokharchenko A, Vajta G, et al. Double vitrification of rat embryos at different developmental stages using an identical protocol. Theriogenology. 2003;60:445-52.

13. Cuello C, Berthelot F, Martinat-Botté F, Venturi E, Guillouet P, Vázquez JM, et al. Piglets born after nonsurgical deep intrauterine transfer of vitrified blastocysts in gilts. Anim Reprod Sci. 2005;85:275-86.

14. Gomis J, Cuello C, Sanchez-Osorio J, Gil MA, Parrilla I. Non-surgical deep intrauterine transfer of superfine open pulled Straw (SOPS)-vitrified porcine embryos: evaluation of critical steps of the procedure. Theriogenology. 2012;78:1339-49.

15. Martinez EA, Martinez CA, Nohalez A, Sanchez-Osorio J, Vazquez JM, Roca J, et al. Nonsurgical deep uterine transfer of vitrified, in vivo-derived, porcine embryos is as effective as the default surgical approach. Sci Rep. 2015;5:10587.

16. Cuello C, Martinez CA, Nohalez A, Parrilla I, Roca J, Gil MA, et al. Effective vitrification and warming of porcine embryos using a pH-stable, chemically defined medium. Sci Rep. 2016;6:101038.

17. Martinez EA, Cuello C, Parrilla I, Martinez CA, Nohalez A, Vazquez JL, et al. Recent advances toward the practical application of embryo transfer in pigs. Theriogenology. 2016;85:152-61.

18. Cuello C, Gil M, Parrilla I, Tornel J, Vázquez J, Roca J, et al. In vitro development following one-step dilution of OPS-vitrified porcine blastocysts. Theriogenology. 2004;62:1144-52.

19. Cuello C, Berthelot F, Delaleu B, Venturi E, Pastor LM, Vazquez JM, et al. The effectiveness of the stereomicroscopic evaluation of embryo quality in vitrified-warmed porcine blastocysts: an ultrastructural and cell death study. Theriogenology. 2007;67:970-82. 
20. Fabian D, Gjørret JO, Berthelot F. Ultrastructure and cell death of in vivo derived and vitrified porcine blastocysts. Mol Reprod Dev. 2005;70:155-65.

21. Cuello C, Berthelot F, Delaleu B, Venturi E, Pastor LM, Vazquez JM, et al. The effectiveness of the stereomicroscopic evaluation of embryo quality in vitrified-warmed porcine blastocysts: An ultrastructural and cell death study. Theriogenology. 2007;67:970-82.

22. Chen YN, Dai JJ, Wu CF, Zhang SS, Sun LW, Zhang DF. Apoptosis and developmental capacity of vitrified parthenogenetic pig blastocysts. Anim Reprod Sci. 2018;198:137-44.

23. Bartolac LK, Lowe JL, Koustas G, Grupen CG, Sjöblom C. Vitrification, not cryoprotectant exposure, alters the expression of developmentally important genes in in vitro produced porcine blastocysts. Cryobiology. 2018;80:70-6.

24. Castillo-Martín M, Yeste M, Pericuesta E, Morató R, Gutiérrez-Adán A, Bonet S. Effects of vitrification on the expression of pluripotency, apoptotic and stress genes in in vitro-produced porcine blastocysts. Reprod Fertil Dev. 2015;27:1072-81.

25. De Oliveira Leme L, Dufort I, Spricigo JFW, Braga TF, Sirard MA, Franco MM, et al. Effect of vitrification using the Cryotop method on the gene expression profile of in vitro-produced bovine embryos. Theriogenology. 2016;85:724-33.

26. Gupta A, Singh J, Dufort I, Robert C, Dias FCF, Anzar M. Transcriptomic difference in bovine blastocysts following vitrification and slow freezing at morula stage. PLoS One. 2017;12:1-20.

27. Aksu DA, Agca C, Aksu S, Bagis H, Akkoc T, Caputcu AT, et al. Gene expression profiles of vitrified in vitro- and in vivo-derived bovine blastocysts. Mol Reprod Dev. 2012;79:613-25.

28. Gupta A, Singh J, Dufort I, Robert C, Dias FCF, Anzar M. Transcriptomic difference in bovine blastocysts following vitrification and slow freezing at morula stage. PLoS One. 2017;12:1-20. e0187268.

29. Aksu DA, Agca C, Aksu S, Bagis H, Akkoc T, Caputcu AT, et al. Gene expression profiles of vitrified in vitro- and in vivo-derived bovine blastocysts. Mol Reprod Dev. 2012;79:613-25.

30. Castillo-Martín M, Yeste M, Pericuesta E, Morató R, Gutiérrez-Adán A, Bonet S. Effects of vitrification on the expression of pluripotency, apoptotic and stress genes in in vitro-produced porcine blastocysts. Reprod Fertil Dev. 2014;27:1072-81.

31. Mantione KJ, Kream RM, Kuzelova H, Ptacek R, Raboch J, Samuel JM, et al. Comparing bioinformatic gene expression profiling methods: microarray and RNA-SEq. Med Sci Monit Basic Res. 2014;20:138-42.

32. Pursel VG, Johnson LA. Freezing of boar spermatozoa: fertilizing capacity with concentrated semen and a new thawing procedure. J Anim Sci. 1975;40:99-102.

33. Martinez EA, Angel MA, Cuello C, Sanchez-Osorio J, Gomis J, Parrilla I, et al. Successful Non-Surgical Deep Uterine Transfer of Porcine Morulae after 24 Hour Culture in a Chemically Defined Medium. Fraidenraich D, editor. PLoS One. 2014;9:1-10. e104696.

34. Funahashi H, Ekwall H, Rodriguez-Martinez H. Zona Reaction in Porcine Oocytes Fertilized In Vivo and In Vitro as Seen with Scanning Electron Microscopy1. Biol Reprod. 2000;63:1437-42. 
35. JM W. Photographic illustrations of embryo developmental stage and quality codes.No Title. In: SM SD and S, editor. Man Int Embryo Transf Soc. Savoy, Illinois, USA: International Embryo Transfer Society. IETS; 1998. p. 167-70.

36. Cuello C, Gil MA, Parrilla I, Tornel J, Vázquez JM, Roca J, et al. In vitro development following onestep dilution of OPS-vitrified porcine blastocysts. Theriogenology. 2004;62:1144-52.

37. Sanchez-Osorio J, Cuello C, Gil MA, Almiñana C, Parrilla I, Caballero I, et al. Factors affecting the success rate of porcine embryo vitrification by the Open Pulled Straw method. Anim Reprod Sci. 2008;108:334-44.

38. Petters RM, Wells KD. Culture of pig embryos. J Reprod Fertil. 1993;48:61-73.

39. Bolstad BM, Irizarry RA, Åstrand M, Speed TP. A comparison of normalization methods for high density oligonucleotide array data based on variance and bias. Bioinformatics. 2003;19:185-93.

40. Bindea G, Mlecnik B, Hackl H, Charoentong P, Tosolini M, Kirilovsky A, et al. ClueGO: a Cytoscape plug-in to decipher functionally grouped gene ontology and pathway annotation networks. Bioinformatics England. 2009;25:1091-3.

41. Cao X, Xu C, Zhang Y, Wei H, Liu Y, Cao J, et al. Comparative transcriptome analysis of embryo invasion in the mink uterus. Placenta. 2019;75:16-22.

42. Pfaffl MW. A new mathematical model for relative quantification in real-time RT-PCR. Nucleic Acids Res. 2001;29:e45e.

43. Lee W-J, Jang S-J, Lee S-C, Park J-S, Jeon R-H, Subbarao RB, et al. Selection of reference genes for quantitative real-time polymerase chain reaction in porcine embryos. Reprod Fertil Dev. 2017;29:357-67.

44. Hsu CC, Lin EC, Chen SC, Huang SC, Liu BH, Yu YH, et al. Differential gene expression between the porcine morula and blastocyst. Reprod Domest Anim. 2012;47:69-81.

45. Tanaka TS, Ko MSH. A global view of gene expression in the preimplantation mouse embryo: Morula versus blastocyst. Eur J Obstet Gynecol Reprod Biol. 2004;115:85-91.

46. Shyh-Chang N, Daley GQ. Metabolic switches linked to pluripotency and embryonic stem cell differentiation. Cell Metab. 2015;21:349-50. Av.

47. Moussaieff A, Rouleau M, Kitsberg D, Cohen M, Levy G, Barasch D, et al. Glycolysis-mediated changes in acetyl-CoA and histone acetylation control the early differentiation of embryonic stem cells. Cell Metab. 2015;21:392-402.

48. Ryall JG, Cliff T, Dalton S, Sartorelli V. Metabolic Reprogramming of Stem Cell Epigenetics. Cell Stem Cell. 2015;17:651-62.

49. Pietrocola F, Galluzzi L, Bravo-San Pedro JM, Madeo F, Kroemer G. Acetyl coenzyme A: A central metabolite and second messenger. Cell Metab. 2015;21:805-21.

50. Kruiswijk F, Labuschagne CF, Vousden KH. P53 in survival, death and metabolic health: A lifeguard with a licence to kill. Nat Rev Mol Cell Biol. 2015;16:393-405.

51. Ozaki T, Nakagawara A. Role of p53 in cell death and human cancers. Cancers. 2011;3:994-1013. 
52. Baumann C, Morris D, Sreenan J, Leese H. The quiet embryo hypothesis: Molecular characteristics favoring viability. 2007;74:1345-53.

53. Leese HJ, Sturmey RG, Baumann CG, McEvoy TG. Embryo viability and metabolism: Obeying the quiet rules. Hum Reprod. 2007;22:3047-50.

54. Leese HJ. Quiet please, do not disturb: A hypothesis of embryo metabolism and viability. BioEssays. 2002;24:845-9.

55. Tribulo P, Moss JI, Ozawa M, Jiang Z, Tian XC, Hansen PJ. WNT regulation of embryonic development likely involves pathways independent of nuclear CTNNB1. Reproduction. 2017;153:405-19.

56. Cadigan KM, Nusse R. Wnt signaling: A common theme in animal development. Genes Dev. 1997;11:3286-305.

57. Galli A, Roure A, Zeller R, Dono R. Glypican 4 modulates FGF signalling and regulates dorsoventral forebrain patterning in Xenopus embryos. Development. 2003;130:4919-29.

58. Mossahebi-Mohammadi M, Quan M, Zhang JS, Li X. FGF Signaling Pathway: A Key Regulator of Stem Cell Pluripotency. Front Cell Dev Biol. 2020;8:1-10.

59. Joeng KS, Schumacher CA, Zylstra-Diegel CR, Long F, Williams BO. Lrp5 and Lrp6 redundantly control skeletal development in the mouse embryo. Dev Biol. 2011;359:222-9.

60. Li X, Zhu L, Yang A, Lin J, Tang F, Jin S, et al. Calcineurin-NFAT signaling critically regulates early lineage specification in mouse embryonic stem cells and embryos. Cell Stem Cell. 2011;8:46-58.

61. Jia B, Xiang D, Liu S, Zhang B, Shao Q, Hong Q, et al. Theriogenology TMT-based quantitative proteomic analysis of cumulus cells derived from vitri fi ed porcine immature oocytes following in vitro maturation. Theriogenology. 2020;152:8-17.

62. Zhao X, Hao H, Du W, Zhu H. Effect of vitrification on the MicroRNA transcriptome in mouse blastocysts. PLoS One. 2015;10:1-14. e0123451.

63. Beyer TA, Narimatsu M, Weiss A, David L, Wrana JL. The TGF $\beta$ superfamily in stem cell biology and early mammalian embryonic development. Biochim Biophys Acta. 2013;1830:2268-79.

64. Mullen AC, Wrana JL. TGF- $\beta$ family signaling in embryonic and somatic stem-cell renewal and differentiation. Cold Spring Harb Perspect Biol. 2017;9:1-32.

65. Kang Y, Chen CR, Massagué J. A self-enabling TGF $\beta$ response coupled to stress signaling: Smad engages stress response factor ATF3 for Id1 repression in epithelial cells. Mol Cell. 2003;11:915-26.

66. Vousden KH, Lu X. Live or let die: The cell's response to p53. Nat Rev Cancer. 2002;2:594-604.

67. Gambino V, De Michele G, Venezia O, Migliaccio P, Dall'Olio V, Bernard L, et al. Oxidative stress activates a specific p53 transcriptional response that regulates cellular senescence and aging. Aging Cell. 2013;12:435-45.

68. Carvajal LA, Manfredi JJ. Another fork in the road - Life or death decisions by the tumour suppressor p53. EMBO Rep. 2013;14:414-21. 
69. Kader A, Agarwal A, Abdelrazik H, Sharma RK, Ahmady A, Falcone T. Evaluation of post-thaw DNA integrity of mouse blastocysts after ultrarapid and slow freezing. Fertil Steril. 2009;91:2087-94.

70. Jaroudi S, SenGupta S. DNA repair in mammalian embryos. Mutat Res - Rev Mutat Res. 2007;635:53-77.

71. Kuscu N, Celik-Ozenci C. FOXO1, FOXO3, and FOXO4 are differently expressed during mouse oocyte maturation and preimplantation embryo development. Gene Expr Patterns. 2015;18:16-20.

72. Ben-Porath I, Weinberg RA. When cells get stressed: An integrative view of cellular senescence. J Clin Invest. 2004;113:8-13.

73. Stelzer G, Rosen N, Plaschkes I, Zimmerman S, Twik M, Fishilevich S, et al. The GeneCards suite: From gene data mining to disease genome sequence analyses. Curr Protoc Bioinforma. 2016;2016:1.30.1-1.30.33.

74. Cuello C, Gil MA, Parrilla I, Tornel J, Vázquez JM, Roca J, et al. Vitrification of porcine embryos at various developmental stages using different ultra-rapid cooling procedures. Theriogenology. 2004;62:353-61.

75. Sanchez-Osorio J, Cuello C, Gil MA, Parrilla I, Maside C, Almiñana C, et al. Vitrification and warming of in vivo-derived porcine embryos in a chemically defined medium. Theriogenology. 2010;73:300-8.

76. Bazer F, Geister R, Thatcher W, Roberts R. No TitleThe establishmentand maintenance of pregnancy. In: Cole DJAFG, editor. Control Pig Reprod. London: Butter-worth Scientific; 1982. pp. 227-52.

77. Meyer AE, Pfeiffer CA, Brooks KE, Spate LD, Benne JA, Cecil R, et al. New perspective on conceptus estrogens in maternal recognition and pregnancy establishment in the pig. Biol Reprod. 2019;101:148-61.

78. Houghton FD. Role of gap junctions during early embryo development. 2002.

79. Arrigo AP. Mammalian HspB1 (Hsp27) is a molecular sensor linked to the physiology and environment of the cell. Cell Stress Chaperones Cell Stress Chaperones. 2017;22:517-29.

\section{Figures}




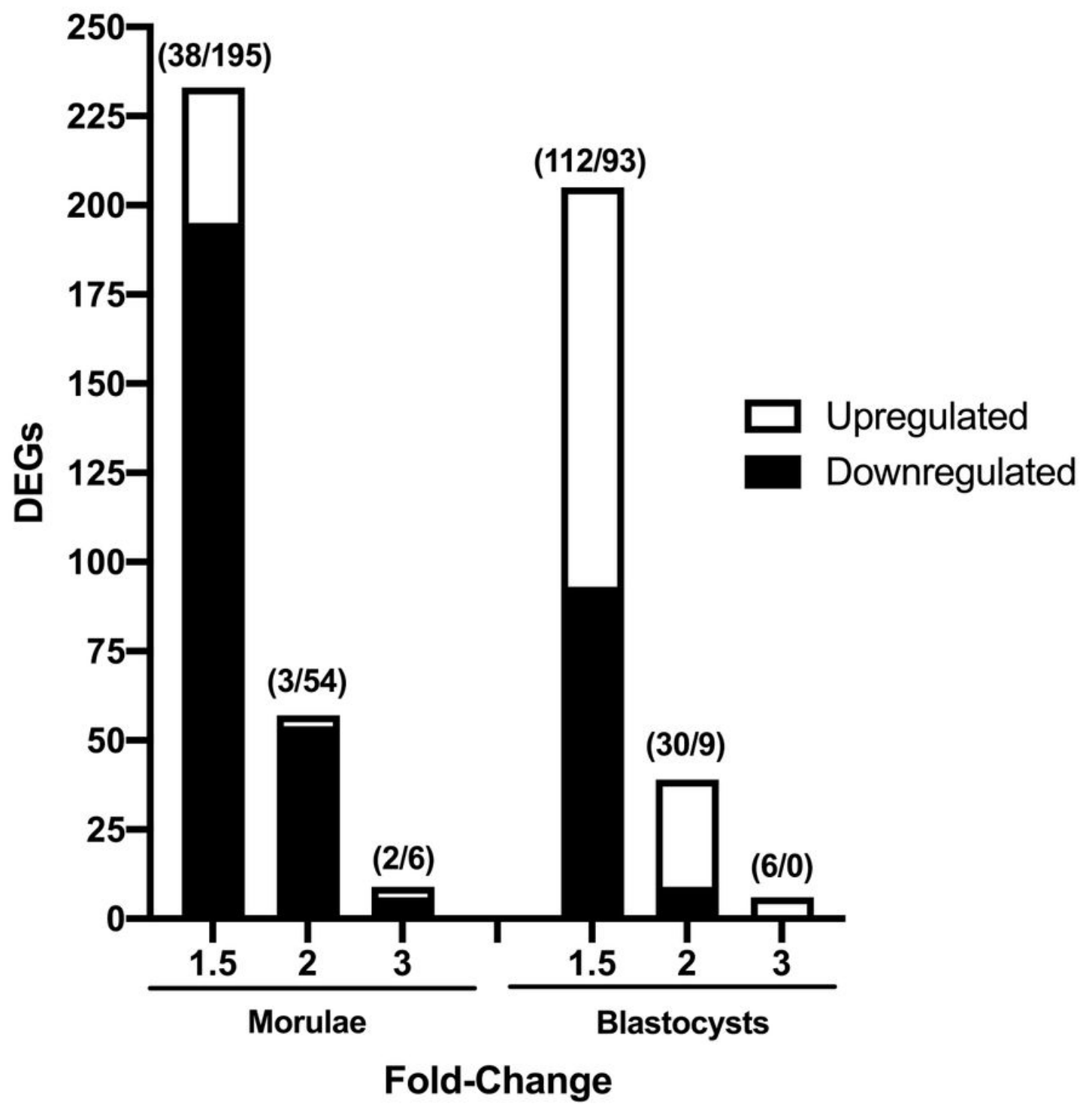

Figure 1

Number of differentially expressed genes (DEGs) identified from the transcriptome analysis of vitrified morulae and blastocysts using different fold-changes $(1.5,2$ and 3 ) values and unadjusted $P$ value < 0.05. Numbers within parentheses represent the number of upregulated and downregulated DEGs. 

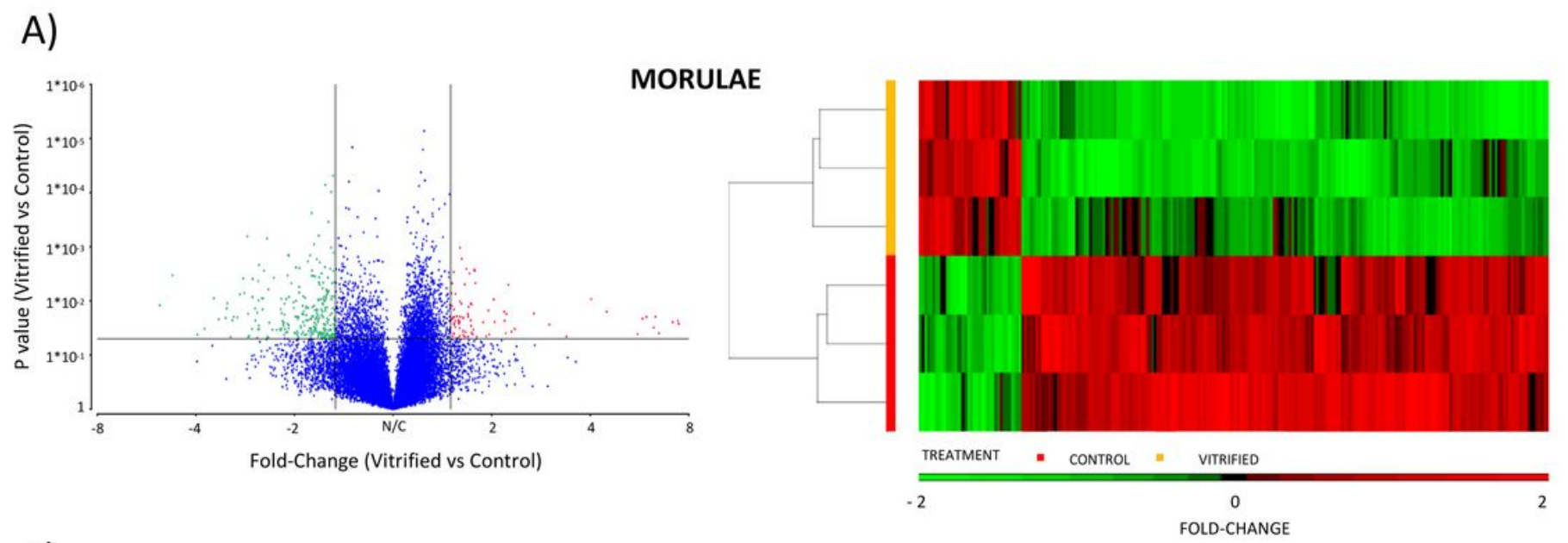

B)


\section{Figure 2}

Volcano plots ( $A$ and $A^{\prime}$ ) of differentially expressed genes (DEGs) between vitrified and control morulae $(A)$ and blastocysts $\left(A^{\prime}\right)$. The significantly upregulated and downregulated genes at a log fold change cutoff of 1.5 and an unadjusted Pvalue $<0.05$ are represented with red and green dots, respectively, while unchanged genes are shown as blue dots. Unsupervised hierarchical clustering analysis of the DEGs of vitrified vs control morulae $(B)$ and blastocysts $\left(B^{\prime}\right)$. Columns and rows represent genes and samples, respectively. The color key under the heat map indicates the different expression levels. 
A) Upregulated DEGs

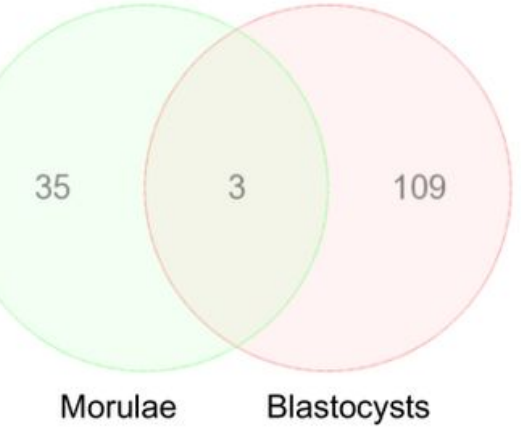

B)

\section{Downregulated DEGs}

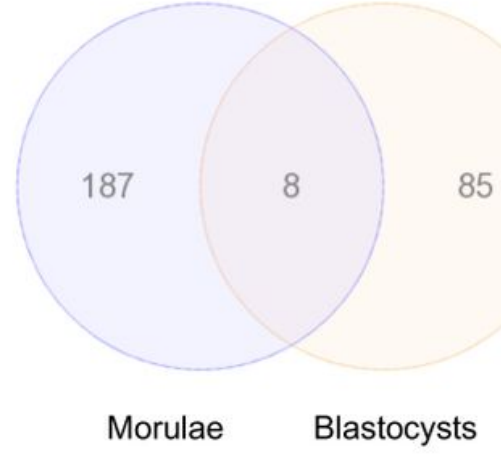

Over-lapping upregulated DEGs between vitrified morulae and blastocysts

\begin{tabular}{|cll|}
\hline Entrez Gene & Gene Symbol & Gene Title \\
\hline 100154420 & LOC100154420 & laminin subunit alpha-2 \\
\hline 100513608 & PLEKHB1 & pleckstrin homology domain \\
\hline 100517736 & SRXN1 & sulfiredoxin-1 \\
\hline
\end{tabular}

Over-lapping downregulated DEGs between vitrified morulae and blastocysts

\begin{tabular}{|c|c|c|}
\hline Entrez Gene & Gene Symbol & Gene Title \\
\hline 100624957 & ZNF786 & zinc finger protein 786 \\
\hline 100153304 & ADO & $\begin{array}{l}\text { 2-aminoethanethiol (cysteamine) } \\
\text { dioxygenase }\end{array}$ \\
\hline 100155047 & MRPL15 & mitochondrial ribosomal protein L15 \\
\hline 503544 & DECR1 & $\begin{array}{l}\text { 2,4-dienoyl CoA reductase } 1 \text {, } \\
\text { mitochondrial }\end{array}$ \\
\hline 100522086 & ART3 & ADP-ribosyltransferase 3 \\
\hline 100522086 & ART3 & ADP-ribosyltransferase 3 \\
\hline 100624754 & SNRNP40 & $\begin{array}{l}\text { small nuclear ribonucleoprotein } 40 \mathrm{kDa} \\
\text { (U5) }\end{array}$ \\
\hline 497233 & CFL2 & cofilin 2 (muscle) \\
\hline
\end{tabular}

\section{Figure 3}

Venn diagrams of the overlap between the up- and downregulated differentially expressed genes (DEGs) of vitrified morulae and blastocysts with respect to their control counterparts. Tables show the lists of the overlapping DEGs for each embryonic developmental stage. 


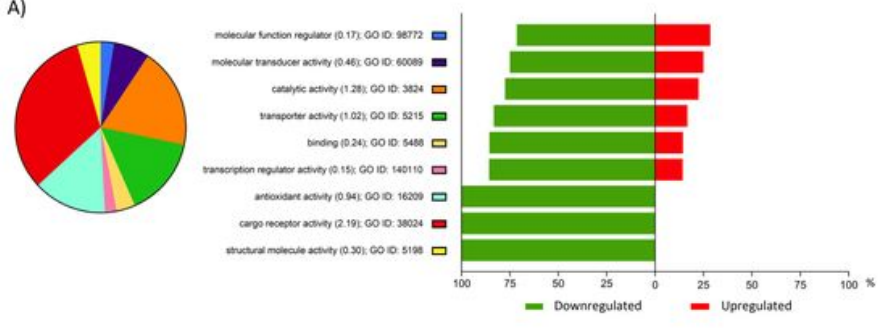

$\left.A^{\prime}\right)$

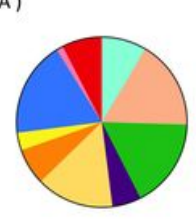

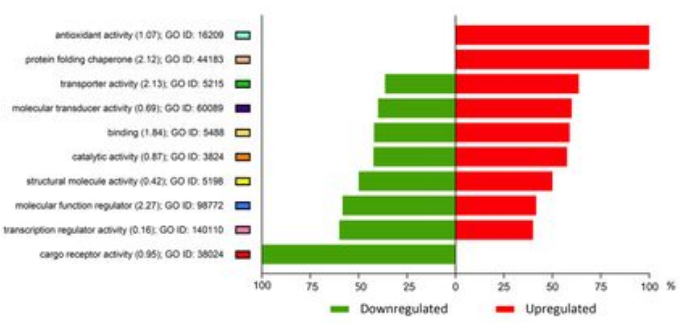

BIOLOGICAL PROCESS

B)
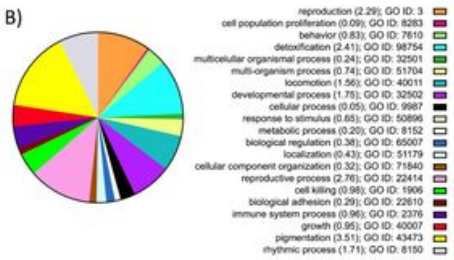

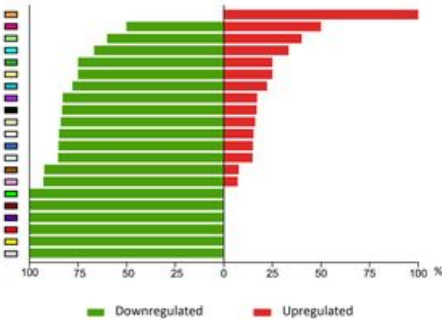

B')


CELLULAR COMPONENT

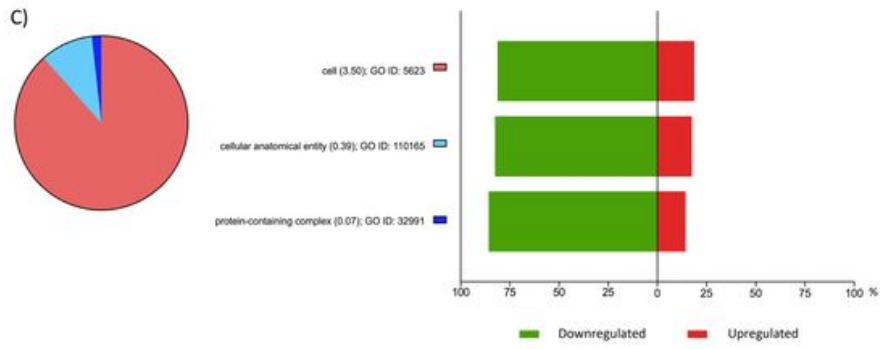

$\left.C^{\prime}\right)$
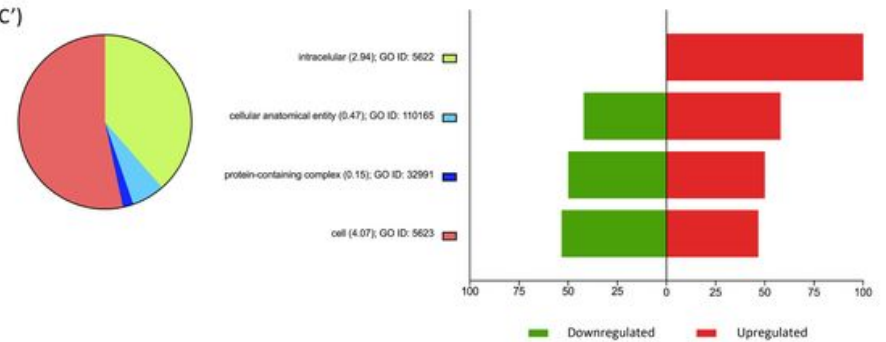

\section{Figure 4}

Pie chart representation of Gene Ontology (GO) terms for differentially expressed genes (DEGs) in vitrified morulae ( $A, B$ and $C$ ) and blastocysts $\left(A^{\prime}, B^{\prime}\right.$ and $\left.C^{\prime}\right)$ analyses and summarized according to molecular function ( $A$ and $\left.A^{\prime}\right)$, biological processes ( $B$ and $\left.B^{\prime}\right)$ and cellular component ( $C$ and $\left.C^{\prime}\right)$. The plots show the percentage of genes associated with each functional group that are upregulated (red) or downregulated (green) in vitrified morulae (A, B and C) and blastocysts (A', B' and $\left.C^{\prime}\right)$. Functional categories of DEGs were obtained using GO annotations from the KEGG classification system. Numbers within parentheses indicate enrichment scores. 


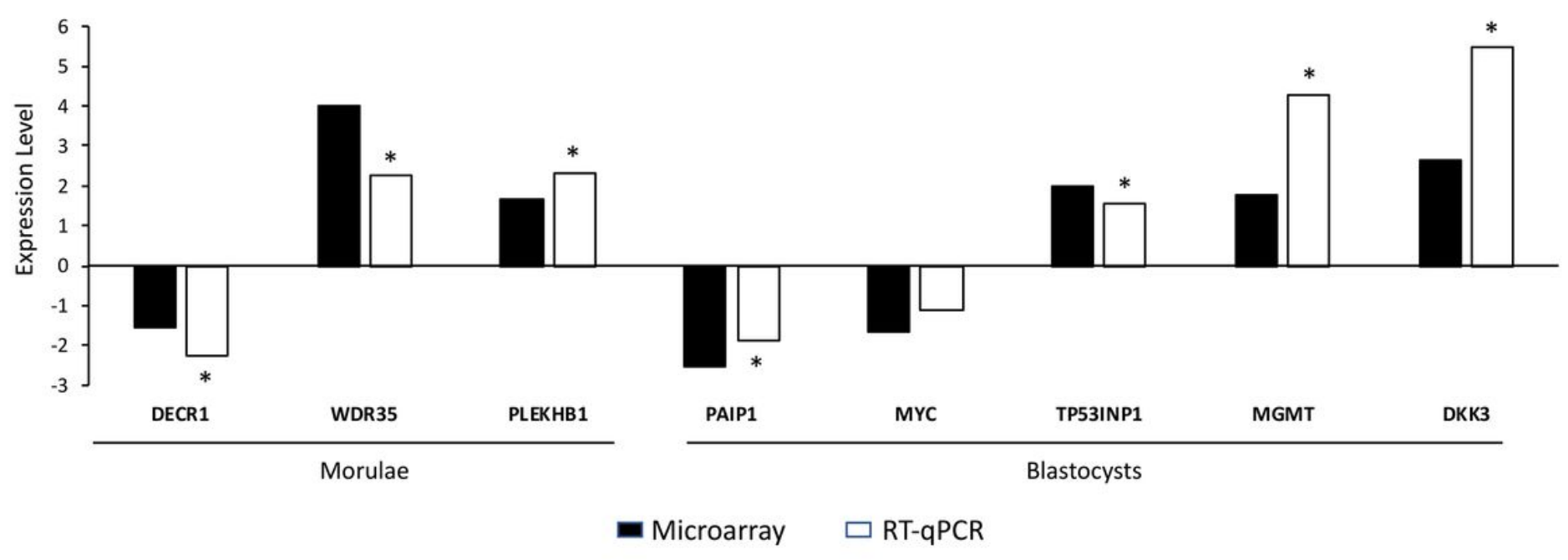

Figure 5

Functionally grouped network-views of enriched pathways obtained from analysis of differentially expressed genes in vitrified morulae (A) and blastocysts (B) compared to control embryos. The networkswere obtained with ClueGo v2.0.3 plug-in from Cytoscape v3.0.0 software. Nodes are colored according to grouping of related pathways and groups are labelled attending to the most significant pathway of the group. Edges indicate interactions between pathways and the node size represents the enrichment significance, where de largest nodes correspond to the highest significance. 
A)

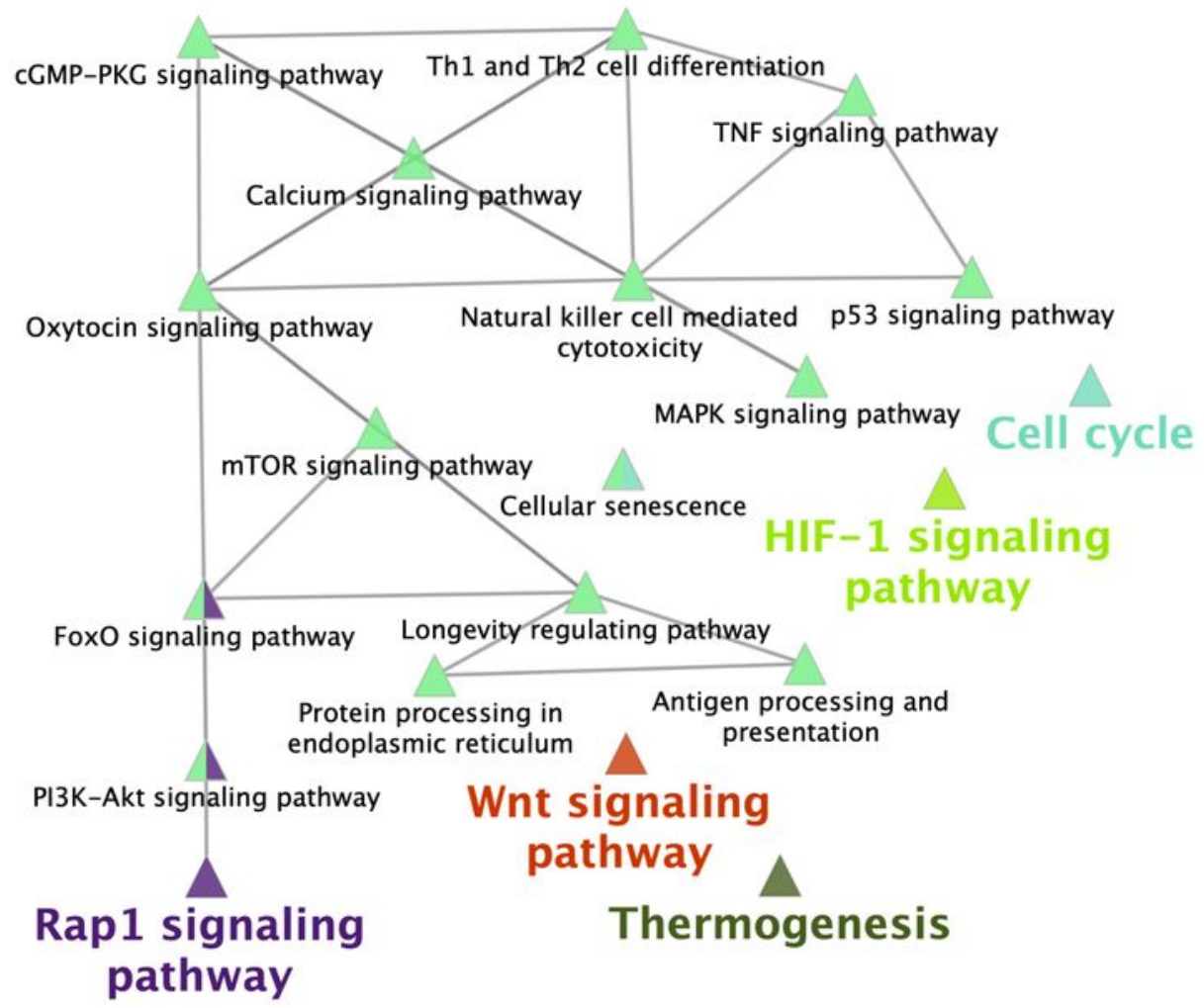

B)

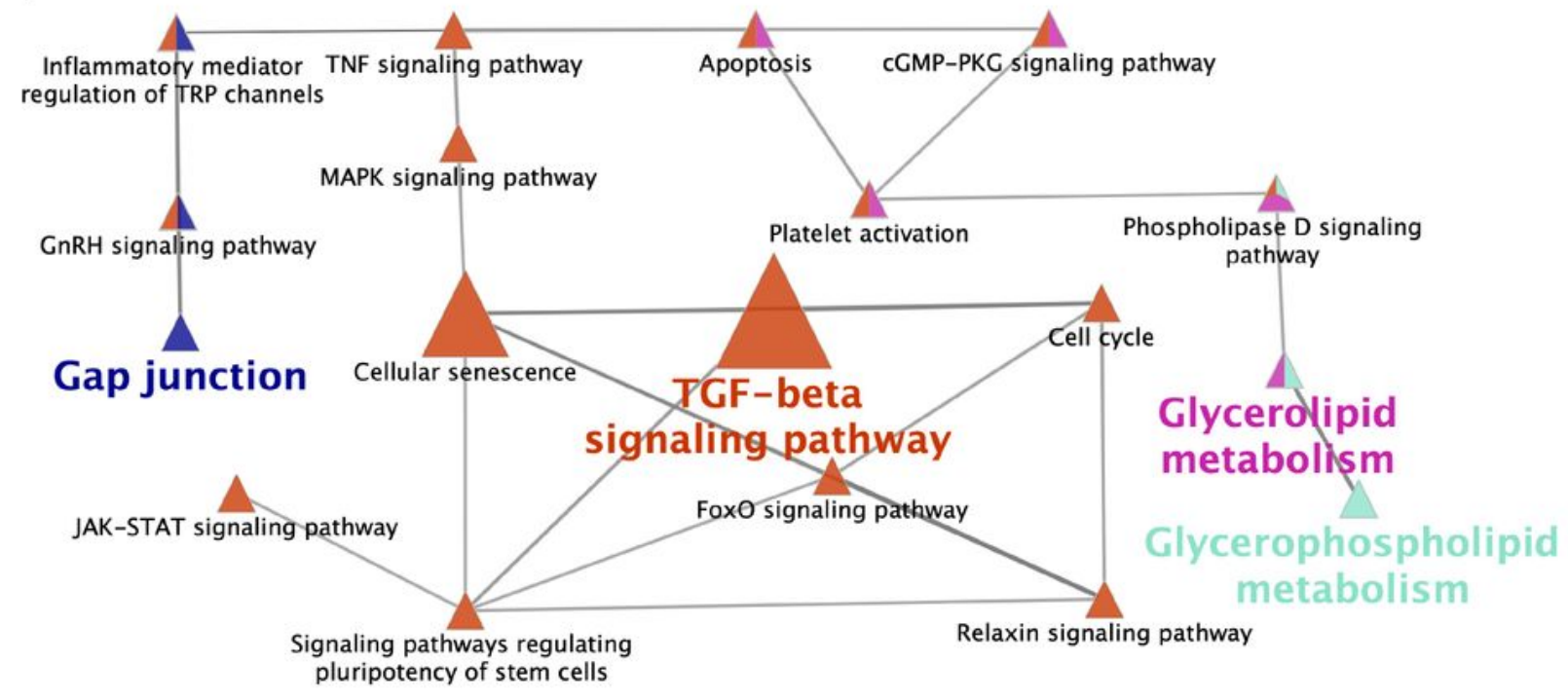

Figure 6

Validation of microarray results by real-time quantitative PCR (qRT-PCR). The Y-axis represents the fold change between the vitrified and control embryos. Asterisks indicate significant differences between vitrified and control groups, as determined by qRT-PCR analysis. 